Available online at: $\mathrm{http}: / /$ proceeding.rsfpress.com/index.php/pss/index

LPPM UPN “Veteran" Yogyakarta Conference Series

Proceeding on Political and Social Science (PSS)

Volume 1 Number 1 (2020): 218-229

\title{
Mapping Of Village Tourism Potential In The Framework Of Implementing Community-Based Tourism
}

\author{
Meilan Sugiarto, Herri Sofyan, Herlina Jayadianti, Rudi Wibowo \\ Universitas Pembangunan Nasional Veteran Yogyakarta \\ E-mail address meilan.sugiarto@upnyk.ac.id
}

\begin{abstract}
There Improvements in the local economy, especially for the poor through open and sustainable tourism management, are believed to be achieved through the empowerment of the tourism sector. Mapping the potential of village tourism in the Triharjo village area is one of the essential things. Identification and mapping of village tourism potential needed in order to implementation community-based tourism (CBT). This research aims to identifying and mapping the potential of village tourism in order to produce a profile of village tourism potential and identify opportunities for developing village tourism potential. The object of this study is Triharjo village, Pandak District, Bantul Regency, Yogyakarta. This research was conducted with a qualitative approach. Collecting data in this study used several research instruments, such as in-depth interviews, focus group discussions (FGD), observations, and document studies. Based on research finding while the communities and local governments of Triharjo village recognize that not all village tourism potentials are well managed. The results of the mapping of village tourism potential provide them that the involvement of local communities in the planning and management of a village tourism potential is needed and have a positive impact on the longterm. The empowerment of the local economy, especially the poor, is believed to be achieved through the empowerment of the tourism sector. Community-based tourism emphasizes community ownership and active participation, provides education to local communities, promotes and protection of culture and the environment.
\end{abstract}

Keywords: village tourism, community-based tourism, poverty, local economy

\section{INTRODUCTION}

This is an open access article under the CC-BY-NC license.

Triharjo Village is a village with the highest poverty percentage in Pandak District, Bantul Regency, approximately $28.97 \%$. Poverty alleviation through improving the local economy is essential for the village. Encouraging village tourism potential has been a prime concern of the village for the last five years. However, the reality several potentials have not been further manageable, and even there is no mapping of the village tourism potential in that 
village. The tourism potential of the village must map, and it needs plans to be more interested.

Improvements in the local economy through empowerment of the tourism sector through the development of micro-businesses that support the local tourism industry, infrastructure development is undertaken by the government to support the tourism industry, and community empowerment through their involvement in deciding the tourism sector (Goodwin \& Robson, 2004). Various studies on the tourism industry in supporting the people's economy have shown many positive impacts (Dritsakis, 2012; Estevão, Cristina, \& Ferreira, 2012). The tourism industry has provided opportunities for local people to meet better job opportunities by becoming workers in the tourism industry, becoming a supplier for the needs of the industry, or being part of other tourism industries.

Study about tourism development and effects on the local communities have become notable to the tourism researchers since many years ago (Lam \& Hsu, 2006). various tourism researchers such as Zhang, YanWu, \& Buhalis (2018), Prayaq et al. (2017), Brida, Osti, and Faccioli (2011), Dyera et al. (2007), and Spanou (2007). Generally, tourism development is always seen as a platform to develop local communities, which leads to community-based tourism (CBT). It needs empowering the local community to provide many benefits (Denman, 2001; Goodwin \& Robson, 2004). Identification and mapping of village tourism potential (Kibicho, 2008) need to be done in order to implement CBT, so it is interesting to study further. In this study, the community is positioned not only as an object of the spillover effect of developing village tourism potential but rather as a subject. The results of this study not only encourage the village government to improve the local economy in the context of poverty alleviation through empowering tourism potentials that exist by the community but also encourage the management of village tourism potential with a welfare approach as well as environmental and cultural preservation. This article contains the results of research that has been carried out for the first year to identify and to map the potential for village tourism in order to produce a profile of village tourism potential and identify opportunities for developing village tourism potential.

\section{LITERATURE REVIEW}

\section{II.1. Tourism Development}

Some types of tourism are particularly appropriate for community-based tourism, for example, ecotourism, ethnic tourism, cultural tourism, village-based tourism, agriculture tourism, and rural tourism, in that they open to community ownership and control (Häusler \& Strasdas, 2003). Tourism development aims to conserve and promote the destination's culture and environment, while at the same time improving the socio-economic welfare of communities (Asker et al., 2010; Vanagas \& Jagminas, 2011). In organizing and promoting tourism, local members are the owners and decision-makers in tourism management for the benefit of their communities. They support cultural and natural heritage preservation and are concerned with the impact of tourism on their communities and the environment. In order to develop and organizing tourism, local members are the owners and decision-makers in tourism management for the benefits of their communities. They support cultural and natural 
heritage preservation and are concerned with the impact of tourism on their communities and the environment. The residents earn income as owners, entrepreneurs, and product and service providers. Typically, they set aside at least part of the tourism income for projects and initiatives that provide benefits to the community as a whole (Asker et al., 2010; Scheyvens, 2007).

Tourism researchers generally agree that it is beneficial for the tourism project to have community involvement in the planning and development stages. Involve communities can enhancing local socio-economic benefits (Mitchell \& Eagles, 2001) also increase the limits of local tolerance through participation by locals in the tourism development process (Tosun, 2000). Assist communities to be more responsive to intensifying competition from the globalization of trade, business, and travel (Jamal \& Getz, 1995), and help secure the commitment of local people, without which the sustainable development of tourism is complicated if not impossible (Sautter \& Leisen, 1999). According to development theory, which focuses on people, grassroots and bottom-up approaches, and local involvement (Horrison \& Schipani, 2007), alternative tourism support types of tourism which are small scale, locally owned, and thought to be less harmful to the environment and culture (Brohman, 1992). They stress equitable participation and empowerment of local communities in decision making and the benefits of tourism (Lanfant \& Graburn, 1992; Scheyvens, 2002).

\section{II.2. Community-Based Tourism}

Community-based tourism is generally understood as nature conservation through ecotourism (Zapata et al., 2011); the concept has been broadening, and an enormous range of tourism products like traditional performances and handicraft productions provided to visitors. Hence, understanding the perceptions from local communities resulted from their active participation and interaction with visitors is very crucial. This understanding benefits the local community equally and ensuring that the supply of tourism products to visitors is continuous. Moreover, the local community has the chance to manage their resources and make decisions for the benefits of the present generation without comprising the organizational structure of the future generation. At this point, CBT portrays the proper management practices resulted from good interaction between the local communities.

Community-based tourism can define as a means of development whereby the social, environmental, and economic needs of local communities are met through the offering of a tourism product (Goodwin \& Santilli, 2009). Community-based tourism believed to have the potential to provide some unique opportunities for communities, not by only offering financial benefits, but by also enhancing their involvement and participation in tourism planning and development in their areas in innovative ways (Johnson, 2010; Lucchetti \& Font, 2013; Razzaq et al., 2012; Salazar, 2012; Vanagas \& Jagminas, 2011).

Community-based tourism focus on the involvement of the host community in the planning, construction, maintenance, and management aspects of tourism development. These imply that the host community' has involvement in, control over, or ownership of the planning outcomes. Tourism literature describes CBT in two ways. One of which focuses on community development through tourism (Blackstock,2005; Kontongeorgopoulos, 2005) 
the second on community engagement with the affected community in the planning of tourism as land use (Mitchell \& Eagles, 2001; Macbeth, Carson, \& Northcote, 2004) and the subsequent development of a tourism venture (Tosun, 2000; Bin \& Nel, 2002) to promote long term relationships between service providers and clients.

\section{RESEARCH METHODOLOGY}

This research was conducted with a qualitative approach so that the data from this study were more descriptive of the form of words and language in a unique natural context and by utilizing various natural methods. However, quantitative data support was also carried out to clarify the description of the phenomena described in the discussion. Collecting data in this study used several research instruments, such as in-depth interviews, focus group discussions (FGD), observations, and document studies. Data collected from various sources such as the head of Triharjo village, the community around the village tourism location, Bantul Regency Tourism Office. At the same time, secondary data was obtained from documents of the Triharjo Village Government, the Bantul Regency Tourism Office, the Bantul Regency regional library, and browsing through the internet network. Furthermore, data analysis is carried out by organizing the data into categories, synthesizing, then arranging them into patterns, selecting and sorting which ones are considered relevant and essential, which are then drawn to conclusions, so that it will facilitate the understanding of researchers and others who read them. Therefore, with a qualitative approach used in this study, the data obtained will be reduced, presented, and conclusions drawn follow the triangulation models.

\section{FINDING AND DISCUSSION}

\section{IV.1. Identification And Mapping of Triharjo village tourism potential}

Mapping tourism potential is considered necessary for each region, wherewith the mapping of tourism potential, it can decide the types and potentials of natural, artificial, religious, and other tourism. Some of them are still in the development stage and has not been operational. The benefit that will obtain from the mapping of tourism potential is that it can determine a destination from which the steps can take for further development planning. Mapping tourism potential also has a positive impact on the community to be able to find out where tourist spots are located and to make it easier for local and foreign tourists to choose the tourist spots they want to visit. Based on observation data and interviews, not all tourism potential in the Triharjo Village area has existed.

\begin{tabular}{cll} 
Tabel & 1. Village tourism potential in Triharjo village \\
\hline No. & Location & $\begin{array}{l}\text { Type of village tourism } \\
\text { potential }\end{array}$ \\
\hline 1 & Siyangan & $\begin{array}{l}\text { Tempuran ngancar } \\
\text { River }\end{array}$ \\
2 & Juwono & River \\
3 & Ngabean & River \\
4 & Gunturan & River \\
5 & Ciren & Sendang Payungan \\
& & Nature \\
\hline
\end{tabular}




\begin{tabular}{lll}
\hline 6 & Jalakan & Sendang Jalakan \\
& & Nature \\
7 & Jigudan & Sendang \\
& & Nature \\
8 & Tirto & - \\
9 & Jaten & Nature \\
10 & Nglarang & Sendang \\
\hline
\end{tabular}

Tempuran Ngancar, Siyangan, Triharjo village

Tempuran Ngancar is located in the Siyangan hamlet, which is a river tourism vehicle because it is surrounded by three large, medium, and small rivers, including the Progo River, the Bedog river, and the channel from the Kamijoro Dam. The existence of this tourism object is marked by a small bridge that crosses the Bedog river and locates near the confluence of the Bedog river and the Progo River. The weakness of these tourism objects is the road conditions to narrow and damage so that it is easier to use two-wheeled vehicles than four-wheeled vehicles, and there are no directions to the location of the tourist attraction, so visitors must ask residents about these locations.
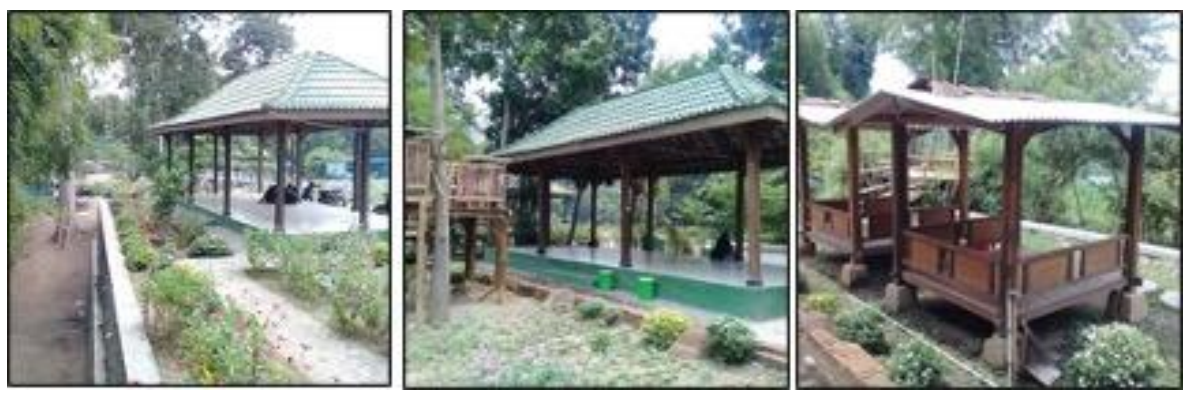

Figure 1. Tourism Potentials of Tempuran Ngancar, Siyangan, Triharjo Village Source: Dok. google.co.id/maps

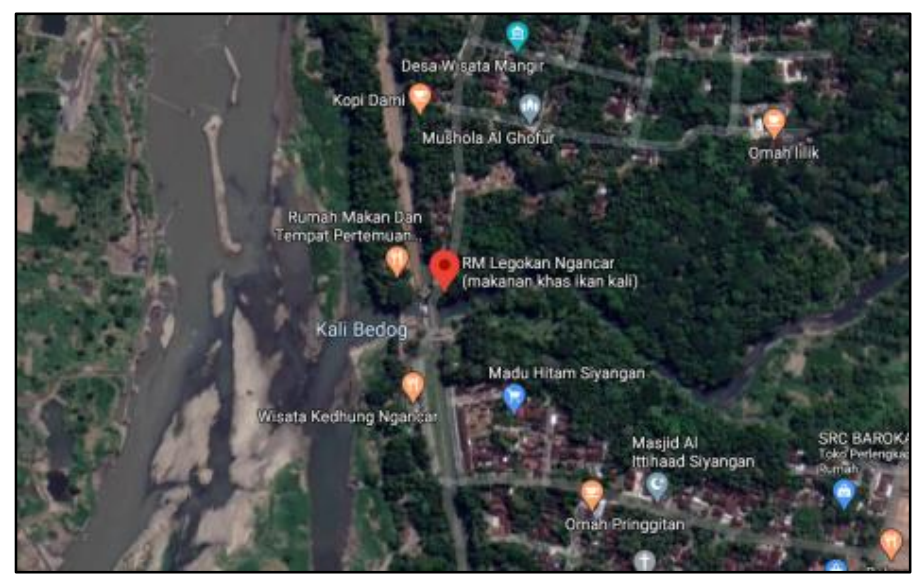

Figure 2. Location Maps of Wisata Tempuran Ngancar, Siyangan, Desa Triharjo Sumber: Dok. google.co.id/maps 


\section{IV.2. Sendang Payungan/Sendang Ciren, Ciren, Triharjo village}

The tourism potential of Sendang Payungan or Sendang Ciren or sometimes known as Sendang Luk Sinangka, is one of the village tourism potentials in Dukuh Ciren, Triharjo Village, Pandak District, Bantul Regency. Based on information obtained from the surrounding community, Sendang Payungan or Sendang Ciren is busy with visitors on weekdays and holidays. This place is lovely and can provide a different sensation from one's daily activities. This Sendang is a religious tourism object. Sendang Payungan has a diameter of about two meters. The depth of the spring is about one meter deep, the lips of the spring covered with several relatively large plants. There are also types of plants, such as Soka, Kepuh, and Preh (a type of banyan) tree. This spring is also equipped with a building like a hall on the north side of the sending. The hall is about seven meters long and about three meters wide. The hall has functioned as a meeting place, a stopover for pilgrims.

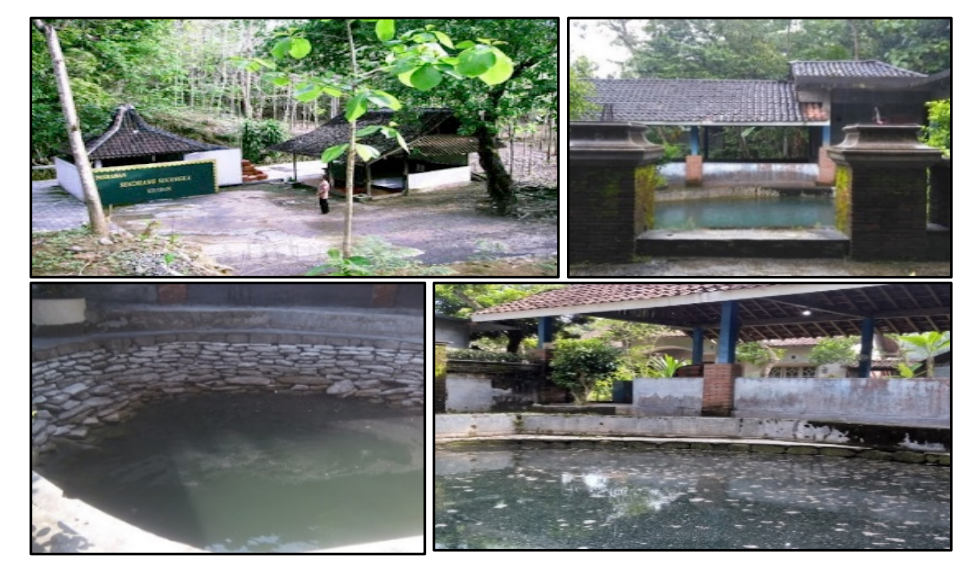

Figure 3. Tourism Potentials of Sendang Payungan, Ciren, Desa Triharjo Sumber: Dok. google.co.id/maps

Some of the available facilities and services include vehicle parking areas, prayer rooms, bathrooms/toilets, rest areas, food stalls, and others. The location of these attractions can reach using private vehicles such as cars or private motorbikes. Visitors who use public transportation can stop at the Bantul city bus terminal, then continue using a motorcycle taxi or private vehicle to Ciren hamlet until they arrive at the Sendang Ciren or Sendang Luk Sinangka tourism location in Bantul Yogyakarta. 


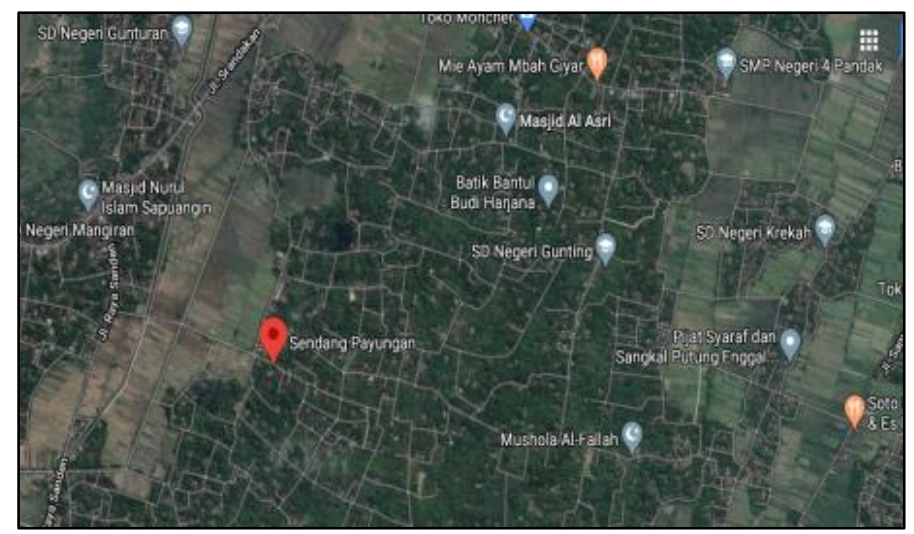

Figure 4. Location Maps of Lokasi of Wisata Sendang Payungan, Ciren, Desa Triharjo Sumber: Dok. google.co.id/maps

\section{IV.3. Sendang Jalakan, Jalakan, Triharjo village}

The tourism potential of Sendang Jalakan is one of the village tourism potentials located in Dukuh Jalakan, Triharjo Village, Pandak District, Bantul Regency. Based on information from the surrounding community, the Sendang Jalakan tourist attraction is crowded with visitors on weekdays and holidays. This Sendang is a historical tourism object. Sendang Jalakan is a water source in Jalakan Hamlet. This sending is not very wide where the surface area or diameter of the sending is approximately 4-5 meters with a depth of approximately 4-5 meters. The water from this spring is relatively straightforward and never dries up during the season, even though in the dry season, the discharge shrinks. This spring is located on the side of the road to enter Jalakan Hamlet. Its existence is now on two sides of the walls of residents' houses. The existence of the spring is also under the shade of several large trees, one of which is the bibs tree (a kind of banyan tree). The existence of Sendang Jalakan is well maintained because it is regularly drained. Besides that, this spring is also protected by a wall fence. The lips of the sending have also hardened with cement. Likewise, the way for the abundance of water from this spring has made a kind of watergate to go to the drain, which then enters the irrigation channel. Besides, the tradition of draining the spring in this place almost always done manually (with a bucket) because there is a belief that if the drain is draining a pump machine, the draining process will not run properly.

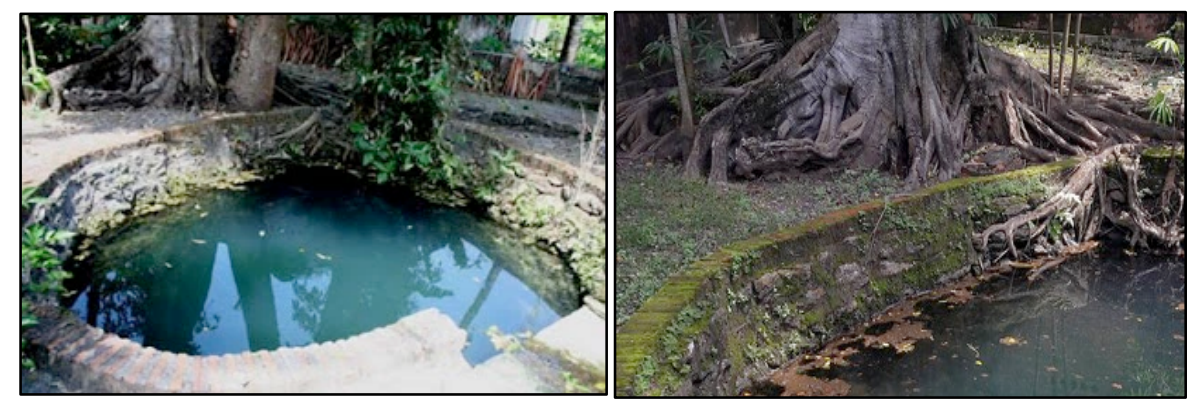

Figure 5. Tourism Potentials of Sendang Jalakan, Jalakan, Desa Triharjo Sumber: Dok. google.co.id/maps 
Some of the available facilities and services include vehicle parking areas, prayer rooms, bathrooms/toilets, rest areas, food stalls, and others. This tourist location can reach by using private vehicles such as cars or private motorbikes. However, if using public transportation such as public buses or other transportation can stop at the Bantul city bus terminal. After that, continue by using a motorcycle taxi to Dukuh Jalakan until we arrive at the location.

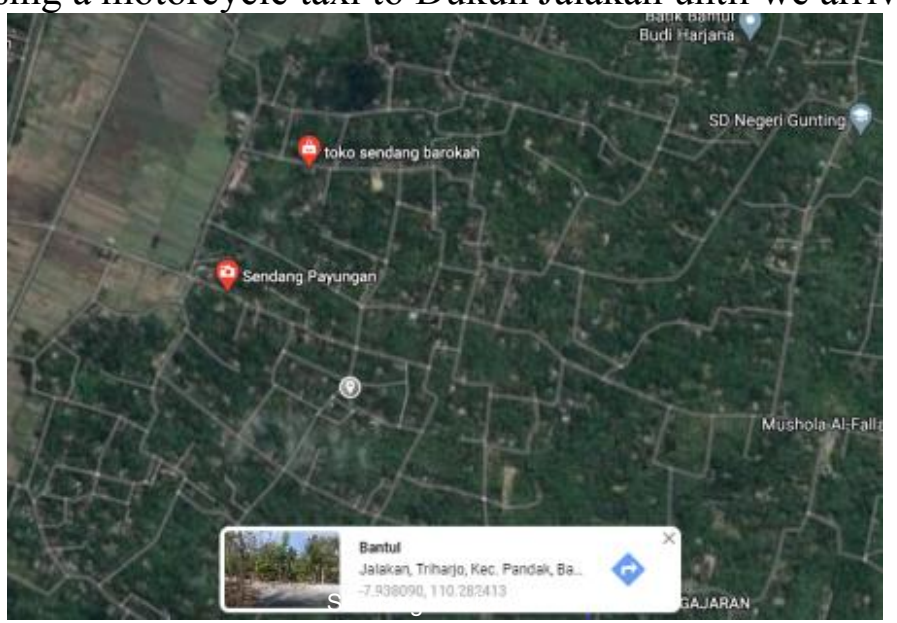

Figure 6. Location Maps of Wisata Sendang Jalakan, Jalakan, Desa Triharjo Sumber: Dok. google.co.id/maps

\section{IV.4.Discussion}

The community development approach to community-based tourism views tourism as an economic driver that enables each community member to have equal access to an improved quality of life. The premise behind tourism in this sense is that the industry will provide economic benefits that are not available from current economic development strategies. The process that the community undergoes in deciding the types of tourism that will be involved in focuses on building capacity. The planning process enables the community to access information regarding tourism; make an informed decision on issues related to tourism; influence the decision-making process, and participate in tourism enterprises.

Community-based tourism management can apply in order to empower the surrounding community, thereby improving local economic conditions (Zapata et al.,2011; Harwood, 2010). Community-based tourism is a form of tourism that prioritizes community ownership and active participation, provides education to local communities and visitors, promotes the protection of culture and the environment, and provides economic benefits to local communities. As a tourism development concept, community-based tourism is not a rigid concept (Tasci, Croes, \& Villanueva, 2014). Implementation of community-based tourism must adapt to the characteristics of a destination, both physical conditions, the community, and other stakeholders, as well as the economic system.

Local communities have a huge role in the sustainability of local tourism in the communitybased tourism, namely as a very substantial control and full involvement in the development and management of local tourism (Denman, 2001). For this reason, tourism development 
can run well managed if it facilitates the broad involvement of local communities in the development process and maximizes the social and economic benefits of tourism activities for the local community. to bring together the natural and cultural environment with tourists. The community will be aware of the commercial value of its natural and cultural heritage, which can generate economic income through tourism. It will encourage people to manage and preserve their natural and cultural environment.

Based on internal conditions of the tourism potential that have previously mapped are the attraction of the tourism potential has not been optimized, so that it is still only a fleeting attraction. Besides, local culture has not been empowered as a scheduled attraction at tourist sites; tourism activities can provide opportunities to empower local communities to contribute to planning and management. There are job opportunities for local communities to improve economic conditions. External conditions that have an impact on village tourism, such as the development of interactive tourism trends between visitors and the surrounding community; natural disasters; disaster mitigation that needs to prepare; government support.

Resources owned by the tourism potential of Triharjo Village are still conventional in offering attractions. Resources in the form of infrastructure are still classified as minimal; apart from that, local wisdom is still limited in its exploitation. People tend to offer attractions that visitors can enjoy in the same tourism objects in other areas so that the uniqueness is not yet visible. Meanwhile, in terms of benefits, the commercialization of the potential for village tourism will have a positive impact in the form of increasing the local economy for the surrounding community, encouraging the surrounding community to be creative, maintaining the existence of local culture by being given a place and time to appear in tourism objects.

In terms of the attraction aspect, the Triharjo Village government with the community need to arrange tour packages based on existing local wisdom to create differentiation with other tourism objects. Develop local cultural attractions, carry out maintenance of tourism objects and environment to keep them attractive. The appeals for attractiveness, such as cleanliness and order, empowering the surrounding community to be creative in making unique souvenirs or collaborating with craft SMEs in the Triharjo Village area. Local government and community have to improve the road to access the tourism objects, installing signs directing visitors to tourist objects, as well as providing traditional local transportation for visitors, especially for tourist locations with limited road access. Meanwhile, from the aspect of amenities, the quality of facilities needs to be improved for the convenience of visitors, it is also necessary to add new facilities, the arrangement of tourist areas also needs to be improved to make it more orderly and attractive.

Role local government itself has seen through the facilitation of activities that raise the potential of local wisdom from each village in its environment. However, from the side of the community around the potential for village tourism, there is still no prominent involvement in the planning and management of tourism potential, for example, the formation of POKDARWIS (tourism awareness groups). These to be needed in the context of empowerment because community involvement in several activities around the village 
tourism objects that have been developed, such as managing parking areas, cleaning staff, selling food, and drinks for visitors. Therefore, the institutional management of village tourism potential is also an important part that needs to be considered, such as improving the quality and capacity of human resources, the synergy of the village government with community groups, partnerships with external stakeholders

\section{CONCLUSION AND FURTHER RESEARCH}

Community-based tourism is an alternative approach that has gained popularity with the government and private sectors as part of the strategies for the conservation of natural resources and development. Mapping the village tourism potential in the Triharjo Village area is essential; mapping the village tourism potential clearly, it will facilitate planning for further development of the village tourism potential. The involvement of local communities in the planning and management of a village tourism potential will have a positive impact because, however, local communities have a huge role in the sustainability of local tourism. Improvement of the local economy, especially for the poor through open and sustainable management, is believed to be achieved through the empowerment of the tourism sector. Community-based tourism emphasizes community ownership and active participation, provides education to local communities and visitors, promotes the protection of culture and the environment, and provides economic benefits to local communities. This concept is not rigid, as explained by Tasci, Croes, \& Villanueva (2014). The clarity of a tourist attraction will be more able to attract visitors and become one of the attractive destinations for tourists, so the crucial aspects that need to consider are the attraction, accessibility, and amenities. Government support in facilitating the development of village tourism potential is needed both programmatically and accidentally. Institutional elements and partnerships with external stakeholders are one of the solutions that need to be taken in developing village tourism potential. The innovation in tourism development tourism based on the community will expand if further research includes other community-based tourism attractions in Triharjo villages or other objects that contribute positively to social, economic, and environmental conditions of the communities.

\section{ACKNOWLEDGMENT}

Research institutions and community service of Universitas Pembangunan Nasional "Veteran" Yogyakarta, Indonesia, which has funded the Cluster Research scheme for the Fiscal Year 2020.

\section{REFERENCES}

Ashley, C., DeBrine, PAL, \& Wilde, H.(2007). The Role of the Tourism Sector in Expanding Economic Opportunity. Corporate Social Responsibility Initiative Report No.23. Cambridge, MA: Kennedy School of Government, Harvard University.

Asker, S., Boronyak, L., Carrard, N., \& Paddon, P. (2010). Effective Community Based Tourism: Best Practice Manual. Gold Coast: Sustainable Tourism Cooperative Research Center. 
Binns, T., \& Nel, E. (2002). Tourism is a local development strategy in South Africa. Geographic Journal, 168, 235-247.

Blackstock, K. (2005). A critical look at community-based tourism. Community Development Journal, 40, 39-49.

Brida, J.G., Osti, L., \& Faccioli, M. (2011). Residents' perception and attitudes towards tourism impacts: A case study of the small rural community of Folgaria (Trentino - Italy), Benchmarking: An International Journal, $18 \quad$ (3), 359-385. https://doi.org/10.1108/14635771111137769

Brohman, J. (1996). New directions in tourism for third world development. Annuals of Tourism Research, 23 (1), 48-70.

Denman, R. (2001). Guidelines for Community-based Ecotourism Development. WWF International.

Dritsakis, N. (2012). Tourism Development and Economic Growth in Seven Mediterranean Countries: A Panel Data Approach. Tourism Economics, 18(4), 801-816. http://users.uom.gr/ drits/publications/TOURISM_DEVELOPMENT.pdf

Dyera, P., Gursoy, D., Sharmaa, B., \& Carter, J. (2007). Structural modeling of resident perceptions of tourism and associated development on the Sunshine Coast, Australia. Tourism Management, Volume 28, Issue 2, Pages 409-422

Estevão, C., \& Ferreira, J.J. (2012). Tourism Cluster Positioning and Performance Evaluation: The Case of Portugal. Tourism Economics, 18 (4), 711-730. https://doi.org/10.5367/te.2012.0137

Goodwin, H., \& Robson, S. (2004). "Tourism and Local Economic Development: How can businesses in travel and tourism increase the contribution of the industry to local economic development and gro-poor http://www.haroldgoodwin.info/resources/Flyer_Final.pdf

Goodwin, H., \& Santilli, R. (2009). Community-Based Tourism: A Success?. Retrieved September 8, 2020, from http://www.icrtourism.org/publications/occasional-paper.

Harwood, S. (2010). Planning for Community Based Tourism in a Remote Location. Sustainability. 2(July), 1909-1923.

Häusler, N., \& Strasdas, W. (2003). Training Manual for Community-Based Tourism. Zschortau: InWEnt-Capacity Building International.

Harrison, D., \& Schipani, S. (2007). Lao Tourism and Poverty Alleviation: CommunityBased Tourism and the Private Sector. Current Issues in Tourism. 10, 194-230. https://doi.org/10.2167/cit310.

http://id.wikipedia.org/wiki/Desa wisata

https://teamtouring.net/

Jamal, T., \& Getz, D. (1995). Collaboration Theory and Community Tourism Planning. Annuals Tourism, 22, 186-204.

Johnson, P.A. (2010). Realizing Rural Community Based Tourism Development: Prospects for Social-Economy Enterprises. Journal of Rural and Community Development, 5, 150162.

Kontongeorgopoulos, N. (2005). Community-Based Ecotourism in Phuket and Ao Phangnga Thailand: Partial Victories and Bittersweet Remedies. Journal of Sustainability Tourism, 13, 4-23. 
Kibicho, W. (2008). Community-Based Tourism: A Factor-Cluster Segmentation Approach. Journal of Sustainable Tourism, 16, 211-231.

Lam, T., \& Hsu, C.H.C. (2006). Predicting behavioral intention of choosing a travel $\begin{array}{llll}\text { destination. } & \text { Tourism } & \text { Management, }\end{array}$ https://doi.org/10.1016/j.tourman.2005.02.003

Lanfant, M., \& Graburn, N.H.H. (1992). International tourism reconsidered: The principle of the alternative. In V.L. Smith \& W.R. Eadington (Eds.), Tourism alternatives: Potentials and problems in the development of tourism, 88-112. Philadelphia, PA: University of Pennsylvania Press.

Lucchetti, V.G.,\& Font, X. (2013). Community-Based Tourism: Critical Success Factors. Retrieved September 10, 2020, from http://www.icrtourism.org.

Macbeth, J.; Carson, D.; \& Northcote, J. (2004). Social Capital, Tourism, and Regional Development: SPCC as a Basis for Innovation and Sustainability. Current Issues in Tourism, 7, 502-521.

Mitchell, R.; \& Eagles, P. (2001). An Integrative Approach to Tourism: Lessons from the Andes of Peru. Journal Sustainable Tourism, 9, 4-28.

Prayag, G., Hosany, S., Muskat, B., \& Del Chiappa, G. (2017). Understanding the Relationships between Tourists' Emotional Experiences, Perceived Overall Image, Satisfaction, and Intention to Recommend. Journal of Travel Research, 56 (1), 41-54. https://doi.org/10.1177/0047287515620567

Razzaq, A.R., Mustafa, M.Z., Suradin, A., Hassan, R., Hamzah, A.,\& Khalifah, Z. (2012). Community Capacity Building for Sustainable Tourism Development: Experience from Miso Walai Homestay. Business and Management Review, 2, 10-19.

Salazar, N.B. (2012). Community-Based Cultural Tourism: Issues, Threats, and Opportunities. Journal of Sustainable Tourism, 20, 9-22.

Sautter, E., \& Leisen, B. (1999). Managing Stakeholders: A Tourism Planning Model. Annual Tourism, 26, 312-328.

Scheyvens, R. (2007). Exploring the tourism-poverty nexus. Current Issues in Tourism, 10(2-3), 231-254.

Spanou, E. (2007). The Impact Of Tourism On The Sociocultural Structure Of Cyprus. Tourism: An International Multidisciplinary Journal Of Tourism, 2(1),145-162.

Tasci, A.D.A., Croes, R., \& Villanueva, Bartels, J. (2014). Rise and fall of communitybased tourism - facilitators, inhibitors, and outcomes. Worldwide Hospitality and Tourism Themes, 6 (3), 261-276. https://doi.org/10.1108/WHATT-03-2014-0012

Tosun, C. (2000). Limits to community participation in the tourism development process in developing countries. Tourism Manage, 21, 613-633.

Vanagas, N.,\& Jagminas, J. (2011). The Potential of Community-Based Tourism Development in Vilnius District Municipality. Management Theory and Studies for Rural Business and Infrastructure Development, 28, 157-163.

Zapata M.J., Hall C.M., Lindo P., \& Vanderschaeghe M. (2011). Can community-based tourism contribute to development and poverty alleviation? Lessons from Nicaragua. Current Issues in Tourism, 14 (8), 725-749.

Zhang, H., YanWu, \& Buhalis, D. (2018). A model of perceived image, memorable tourism experiences, and revisit intention. Journal of Destination Marketing \& Management, 8, 326-336. https://doi.org/10.1016/j.jdmm.2017.06.004 